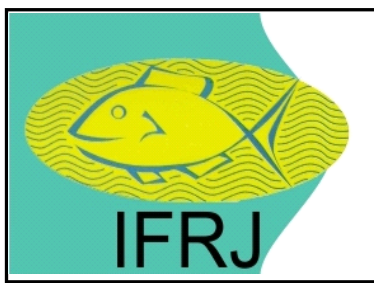

Available online at: http://ejournal-balitbang.kkp.go.id/index.php/ifrj

e-mail:ifrj.puslitbangkan@gmail.com

INDONESIANFISHERIES RESEARCHJOURNAL

Volume 25 Nomor 1 June 2019

p-ISSN: 0853-8980

e-ISSN: 2502-6569

Accreditation Number RISTEKDIKTI: 21/E/KPT/2018

\title{
POPULATION PARAMETERS OF ENDEAVOUR SHRIMP (Metapenaeus ensis de Haan) IN BINUANGEUN AND ADJACENT WATERS, WEST JAVA
}

\author{
Ali Suman ${ }^{\star 1}$, Prihatiningsih ${ }^{1}$, Pratiwi Lestari ${ }^{1}$ and Andina Ramadhani Putri Pane ${ }^{1}$ \\ ${ }^{1}$ Researcher in Research Institute for Marine Fisheries, Jalan Raya Bogor Km. 47 Nanggewer Mekar, Cibinong-West Java, Indonesia \\ Received; January 02-2019 Received in revised from February 26-2019; Accepted February 28-2019
}

\begin{abstract}
Study on the population dynamic of endeavour shrimp (Metapenaus ensis) was conducted in Binuangeun waters based on data collected during period of survey, January to November 2016. The purpose of the study was to identify population parameters of the endeavour shrimp. Result showed that the endeavor shrimp growth pattern in Binuangeun waters was negative allometric and sex ratio of males and females was $1.0: 2.7$. The chi square test indicated that comparison of male and female of the endeavour shrimp was significantly different. It mean that there was imbalance in number between males and females. The length at first capture $\left(L_{c}\right)$ of endeavour shrimp was $28.9 \mathrm{~mm}$ (carapace length), smaller than the length at first maturity $\left(\mathrm{L}_{\mathrm{m}}\right)$ at $37.7 \mathrm{~mm}$ (carapace length). The growth parameter of endeavour shrimp was 1.33 /year with maximum carapace length (Loo) of $51.45 \mathrm{~mm}$. Instantenous total mortality $(Z)$ and natural mortality (M) were 7.74/year and 1.88/year, respectively. While fishing mortality $(F)$ and exploitation rate $(E)$ respectively were 5.86/year and 0.76/year. The exploitation rate of endeavour shrimp in Binuangeun and adjacent waters was high. It was, therefore, recommended that fishing effort of the endeavour shrimp in that waters should be reduced about $52 \%$ in the next year.
\end{abstract}

Keywords: Population dynamic; endeavour shrimp; Binuangeun waters; FMA 573

\section{INTRODUCTION}

Endeavour shrimp (Metapenaeus ensis) is one of penaeid shrimp species which is dominantly caught in south coast waters of Java include in Binuangeun and adjacent waters. Catch of endeavour shrimp was the second highest after others shrimp (Parapenaeopsis spp.) (Suman, 2004; RIMF, 2016).

Exploitation of the endeavour shrimp in Binuangeun and adjacent waters has taken place since long time ago (Van Zalinge \& Naamin, 1975) and become more intensive in the recent years due to an increase of local and or foreign market demand (RIMF, 2016). If this situation continues to occur, sustainability of the shrimp stock will be disturbed in the future. Therefore comprehensive research is needed to reach rational utilization in order to maintain sustainability of the stock for prosperity purpose in the future (Naamin et al., 1992; Suman et al., 2014).
This paper discussed population parameters of the endeavour shrimp ( $M$. ensis) in Binuangeun and adjacent waters. It is hoped that the result can be used as basic and important information for sustainable management of the endeavour shrimp and other endeavor studies in Binuangeun and adjacent waters.

\section{MATERIALS AND METHODS}

Samples of the endeavour shrimp were taken from field research in Binuamgeun and adjacent waters (Figure 1) from January 2016 to November 2016. Biometric studies (carapace length, sex and gonad maturity identifications) were done for 1,548 samples. The relationship between the endeavour carapace length and weight follows the cubic law (Bal \& Rao, 1984; King, 1995): $\mathrm{W}=\mathrm{aL}^{\mathrm{b}}$, with $\mathrm{W}$ as the weight (gram); $L$ as the carapace length $(\mathrm{mm})$ and $a, b$ as constants. The sex ratio was calculated by comparing the number of male and female and analyzed to know whether the sex ratio is balance or not by using the Chi-square test (Walpole, 1993). 


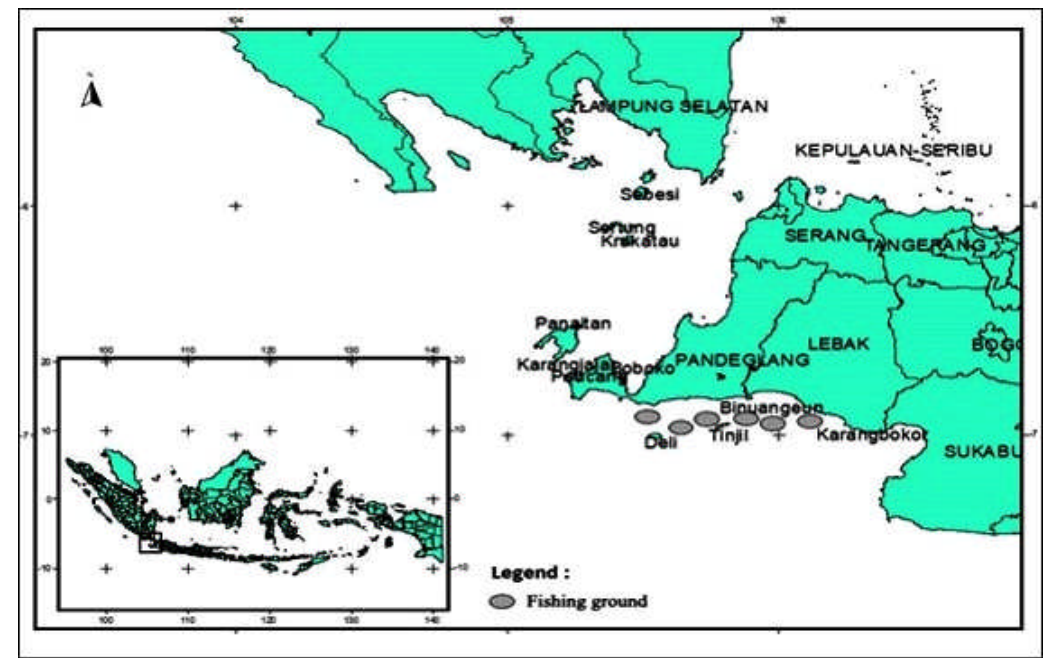

Figure 1. The fishing ground of endeavour shrimp ( $M$. ensis) in the Binuangeun and adjacent waters.

The calculation of the length at first capture (LC) was done using the equation as follows (Sparre \& Venema, 1992):

$$
S_{L}=\frac{1}{1+\exp (S 1-S 2 x C)} ; \operatorname{Ln}\left[\left(\frac{1}{S_{L}}\right)-1\right]=S 1-S 2 x L \ldots . .(1)
$$

where SL is the logistic curve and S1 and S2 are constants in the logistic curve equation.

Spearman-Karber method (Udupa, 1986) was applied to identify the size at first maturity with assumption that average size of first maturity occurs when $50 \%$ of the endeavour shrimp is already mature. Logarithmic size of the first sex mature $(\mathrm{m})$ was calculated based on equation below:

$$
m=x . k+\frac{X}{2}-\left(x \sum p i\right)
$$

where:

$\mathrm{m}$ : logarithmic size of first sex mature,

xk : logarithmic size of mean value of $100 \%$ mature,

$X$ : logarithmic different of mean value, and

pi : comparison of sex maturity of each length class

In this classification, gonad maturity stage (GMS) I and II are classified as immature while GMS III, IV and $\mathrm{V}$ are mature. The GMS was morphologically identified based on sex maturity stage of the shrimp (Tuma, 1967 vide Naamin, 1984) namely: I = quiescent/undeveloped, II = developing, III = early maturity, IV = ripe, and $\mathrm{V}=$ spent.

Growth rate $(\mathrm{K})$ and maximum carapace length (Loo) were analysed by tracing modus of monthly carapace length distribution using ELEFAN program (Sparre \& Venema, 1992; Gayanilo et al., 2005). Total mortality (Z) was calculated from catch curve (Sparre \& Venema, 1992; Gayanilo et al., 2005) and natural mortality (M) was predicted using combination of Pauly empiric equation (Pauly,1985) and fishing mortality rate $(F)=Z-M$, while exploitation rate $(E)=F / Z$ (Sparre \& Venema, 1992).

\section{RESULT AND DISCUSSION}

\section{Result}

\section{The Relationship Between Length-Weight and Sex Ratio}

The growth pattern of male and female of endeavour shrimp was allometric negative (Figure 2), indicating the carapace length increase in endeavour shrimp was faster than the body weight gain.

Chi-square test informed that value of male and female was imbalance, it was also identified that sex ratio of the endeavour shrimp in Binuangeun and adjacent waters was found to be $1.0: 2.7$.

\section{The Length at First Capture (LC) and the Length At First Maturity (Lm)}

From the analysis using a logistic curve of endeavour shrimp, it shows that the Lc was found at a carapace length $(\mathrm{CL})$ of $28.9 \mathrm{~mm}$ (Figure 3 ). 


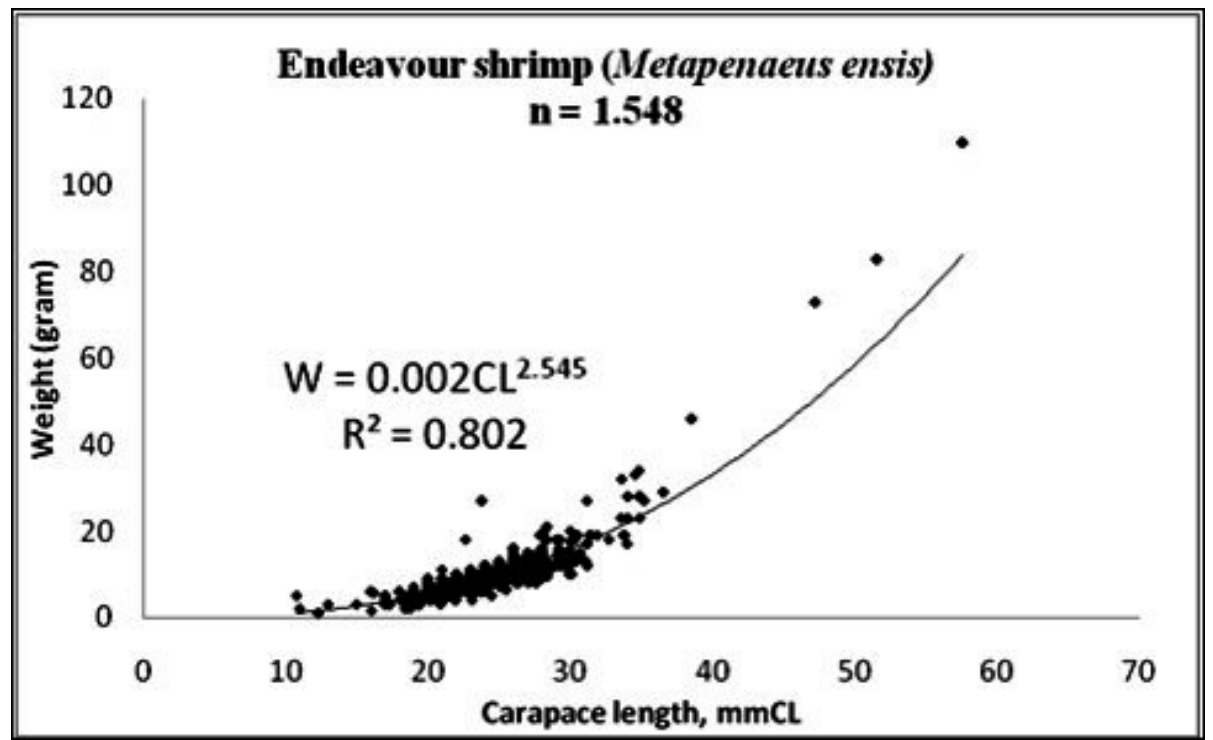

Figure 2. The relationship between length-weight of endeavour shrimp (M. ensis) in Binuangeun and adjacent waters.

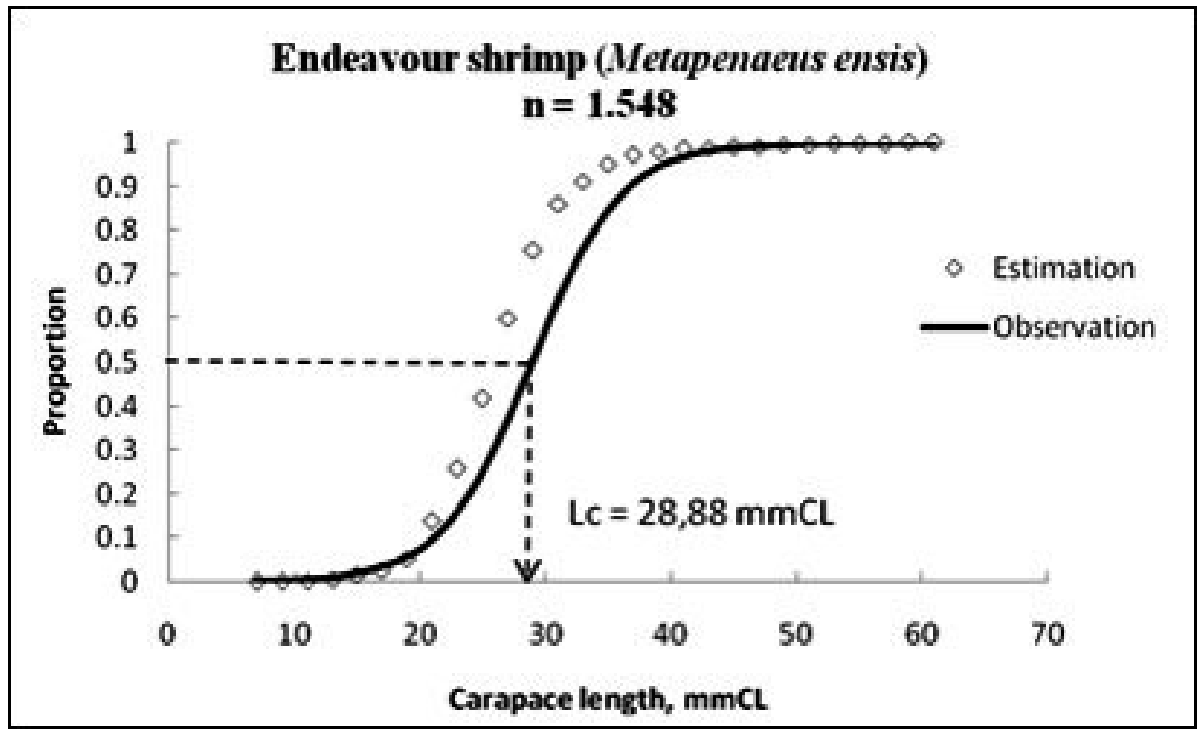

Figure 3. Length at first capture of endeavour shrimp (M. ensis) in Binuangeun and adjacent waters.

Meanwhile, the endeavour shrimp analyzed using a Spearman-Karber method reaching at the length at first maturity (Lm) was in average at $37.7 \mathrm{~mm}$ (carapace length).

\section{Growth Parameter}

Basically, ELEFAN program is applied to interpret carapace length in time series data adjusted with von Bertalanffy growth curve. Value of growth rate $(K)$ and maximum carapace length (Loo) of endeavor shrimp was recorded by identifying monthly carapace length frequency (Figure 4) namely 1.33/year and $51.45 \mathrm{~mm}$.

\section{Mortality Rate and Exploitation Rate}

Value of total mortality $(Z)$ represented by value of slope (b) between $\mathrm{Ln} \mathrm{N/t}$ and relative age (Figure 5) was $7.74 /$ year. Meanwhile value of natural mortality (M) and fishing mortality $(F)$ were 1.88/year and 5.86/ year, respectively.

Using exploitation rate equation $(E)=F / Z$, it was obtained that $E$ of endeavour shrimp in Binuangeun and adjacent waters was $0.76 /$ year. 


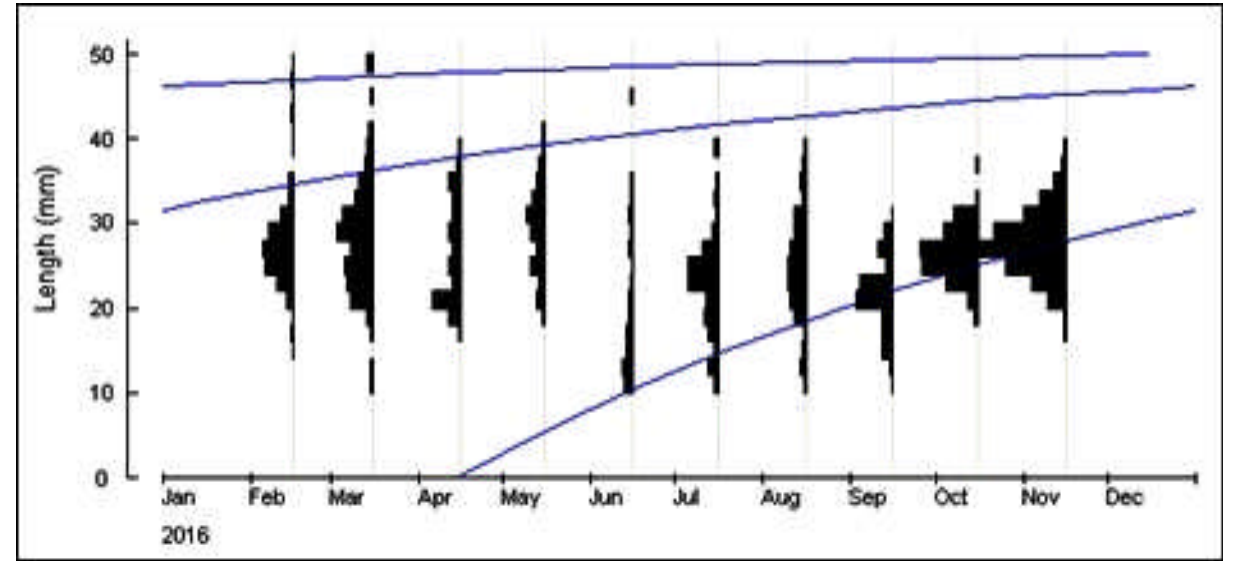

Figure 4. Carapace length distribution of endeavour shrimp (M. ensis) in Binuangeun and adjacent waters.

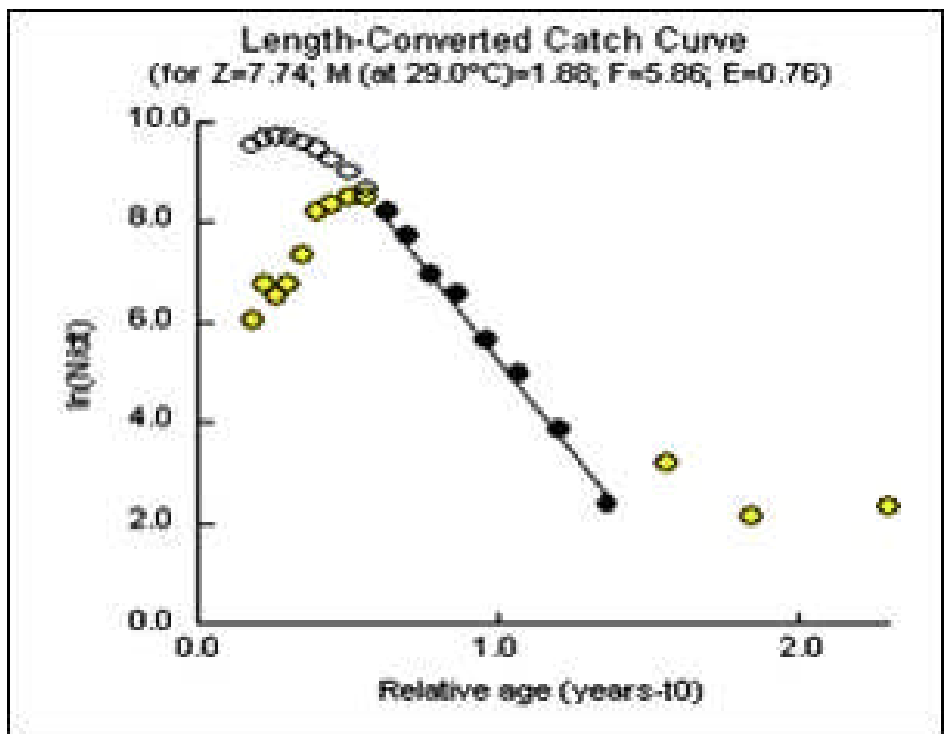

Figure 5. The value of total mortality ( $Z$ ) of endeavour shrimp (M. ensis) in Binuangeun and adjacent waters.

\section{Discussion}

The analysis of the relationship between carapace length and weight was used to discover the growth pattern of endeavor shrimp in Binuangeun and adjacent waters. The result of the t-test showed that the endeavour shrimp growth pattern was negative allometric. This growth pattern suggested that the increase in carapace length was faster than the weight gain. This same from the results obtained by Herdianto \& Riswanto. (2014) who found that the growth pattern of endeavour shrimp in the waters of Kubu Raya was negative allometric. This growth pattern depends on the availability of food and the water temperature (Monterio, 2002 in Fauzi et al., 2013). Differences in length increase could also be caused by differences in external and internal factors. According to Effendie (2002), internal factors are factors that are difficult to control such as genetics, sex, age, and diseases. On the other hand, the main external factors that influence fish growth are temperature and food.
Data on sex ratio of shrimp stock are important and as basic information for reproduction biology of the stock (Suhendrata \& Merta, 1986).Sex ratio of male and females endeavour shrimp was imbalance $(1.0: 2.7)(p<0.05)$. The dominant of female indicates that the recovery of population in these waters will not disturb (Naamin, 1984). This finding is similar to that reported from Kebumen waters (Suparjo, 2005). These data were quite different with data reported by previous researchers. Suman et al. (1987) reported that sex ratio of male and female endeavour shrimp in Pangandaran waters was $1.0: 1.2$ while in Kotabaru waters (South Kalimantan), the sex ratio of shrimp was $1.0: 2.5$ (Suman, 1991). This phenomenon possible occurred due to the different analysis of male and female sex ratios done prior to and during spawning season (Nikolsky, 1963).

Shrimp age and the length at first maturity is important for management purpose because exploitation has to let some stocks which have the 
same or bigger size when they reach maturity still life (Sudjastani, 1974). The length at first maturity (Lm) of the endeavour shrimp in Binuangeun waters was $37.7 \mathrm{~mm}$ in carapace length. The $\mathrm{Lm}$ value found in this study is slightly higher than those reported for endeavour shrimp of Tanjung Krawang was $20 \mathrm{~mm}$ (Martosubroto, 1978), South Coast of Java waters was $36,8 \mathrm{~mm}$ (Suman, 1990) and Cilacap waters was 31,80 mm (Suman \& Boer, 2005). Nikolsky, (1963) stated that $L m$ value is influenced by some factors, such as: depth and type of habitat in association with food availability, temperature, and light. According to Sivakami et al. (2001), the difference in $\mathrm{Lm}$ value for each fish is caused by the difference size of samples collected, the maximum and minimum length, and frequency of fish that are gonad-mature. So allegedly that the availability of food and environment condition in Binuangeun waters are better than the some waters.

Further analysis showed that the length at first capture (Lc) of endeavour shrimp in the Binuangeun waters was smaller than the length at first maturity (Lm). This condition is unexpectable in term of fisheries management. It was recommended that $\mathrm{Lm}$ value was larger than $L c$ value. If this condition is left for long period, the stock of endeavour shrimp in Binuangeun waters would continue to decrease until a level in which the endeavour shrimp stock will be disrupted and finally no more endeavour shrimp stock available in the waters enough as a fishery resource. In contrast, if $\mathrm{Lc}$ is higher than $\mathrm{Lm}$, it means that the individuals of shrimp have changes to spawn to maintain its population. In order to ensure the sustainability of the resources, the fishing pattern should allow a number of shrimps brood stock to escape (Sudjastani, 1974). To prevent stock degradation in the Binuangeun waters, a regulation for net mesh size is needed in catching of endeavour shrimp.

According to Sparre \& Venema (1992), the lower growth coefficient $(K)$ needed the longer time for the species to reach asymptotic length. On the other hand, the higher growth coefficient needed the shorter time by the species to approach the asymptotic length. The growth rate $(K)$ of endeavour shrimp in the Binuangeun waters was 1.33 per year and this showed that the growth rate was considered fast (Sparre \& Venema, 1992). Therefore care must be taken when planning the amount of effort allowed to be applied each year for exploiting the shrimp stock in order to obtain rational management of the stock. If value of recommended effort was lower, uncapture shrimp stock would be useless or number of natural mortality would be high because the growth type of the stock was fast growth. It mean that the stock had short life span. In contrast, if value of recommended effort was higher, the stock would be disturbed, even jeopardized because there was no enough time for population members renew the stock which led the decrease of recruitment number and amount of next year stock. This phenomenon differed from the results of other studies in various waters (Table 1).

Table 1. The growth rate (K) and maximum carapace length (Loo) of endeavour shrimp (M. ensis) in some waters area

\begin{tabular}{clc}
\hline Waters & K (per year) Loo $(\mathbf{m m})$ & Source \\
\hline Binuangeun & 1.3351 .45 & this research \\
South Coast of Java & $1.61-1.6352 .2$ & Suman (1992) \\
Cilacap & $1.49-1.5241 .5-52.2$ & Suman \& Boer $(2005)$ \\
Balikpapan & 1.6042 .0 & Suman \& Bintoro (2009) \\
Arafura Sea & 1.3352 .0 & Suman et al. (2017) \\
Bangka Strait & $1.40-1.4545 .0-49.5$ & Lestari et al. (2018) \\
\hline
\end{tabular}

Differences in the growth parameter could be caused by differences in the maximum length of the samples collected and differences in the location of the waters (Widodo \& Suadi, 2006). Knaepkens et al. (2002) and Effendie (2002) stated that differences in the values of $\mathrm{K}$ and Loo are caused by internal/ intrinsic and external factors. Internal factors that influential are genetics, parasite infestations, and diseases, while the external factors are temperature and availability of food.
The total mortality rate $(Z)$ is a combination between the natural mortality rate $(\mathrm{M})$ and the fishing mortality rate (F) (Sparre \& Venema, 1992). Instantenous total mortality rate $(Z)$, natural mortality rate $(M)$ and fishing mortality rate $(F)$ were 7.74 /year, 1.88/year and 5.86/ year, respectively. This phenomenon differed from the results of other studies in various waters (Table 2). 
Table 2. The total mortality $(\mathrm{Z})$, natural mortality rate $(\mathrm{M})$ and fishing mortality rate $(\mathrm{F})$ of endeavour shrimp (M. ensis) in some waters area

\begin{tabular}{clc}
\hline Waters & Z M F & Sumber (Source) \\
\hline Binuangeun & 7.741 .885 .86 & this research \\
South Coast of Java & $6.9-7.12 .2-2.14 .7-5.0$ & Suman, (1992) \\
Cilacap & $6.5-8.72 .0-2.14 .5-6.6$ & Suman \& Boer (2005) \\
Balikpapan & 4.522 .182 .34 & Suman \& Bintoro (2009) \\
Arafura Sea & 4.791 .882 .91 & Suman et al. (2017) \\
Bangka Strait & $4.0-4.62 .02 .0-4.6$ & Lestari et al. (2018) \\
\hline
\end{tabular}

It was presented that differences in value of shrimp mortality rates in several waters (Table 1) were caused by different level of effort number, predator and environment condition (Pauly et al., 1984). The M value of endeavour shrimp in several waters appeared to be smaller than the $F$ value, and this suggests that most of the endeavour shrimp in the Binuangeun waters died due to capture.

Using exploitation rate equation $(E)=F / Z$, it was obtained that $E$ of endeavour shrimp in the Binuangeun waters was $0.76 /$ year. Based on Pauly criterion (Pauly et al., 1984), it was concluded that over fishing of the shrimp stock has occurred in the Binuangeun waters because rational fishing of fish or shrimp stock can be gained if values of $E$ in that waters equals 0.5 . If value of $E$ is more than 0.5 , the stock will be endangered thus effort has to be decreased in order to sustain the stock. Phenomenon of the endeavour shrimp stock in the Binuangeun waters suggested that fishing effort of the endeavour shrimp stock should be lowered until $52 \%$ of the present status.

\section{CONCLUSION}

The growth pattern of endeavour shrimp (M. ensis) in Binuangeun and adjacent waters was negative allometric and this suggested that the body width growth was faster than that of the weight gain. The length at first capture (LC) which is smaller than the length at first maturity $(\mathrm{Lm})$ may disturb endeavour shrimp resource sustainability. The growth rate and the mortality rate of endeavour shrimp ( $M$. ensis) were classified as high. The exploitation rate of endeavour shrimp resources in Binuangeun waters was already classified as overfishing category. To ensure the waters sustainability, regulated on the net mesh size and a reduction of approximately $52 \%$ of the current fishing effort is advisable. For determining of the net mesh size, it is still needed further research in these waters. In addition, an assessment of the socio-economic aspect may result to a more accurate stock status of endeavour shrimp in Binuangeun and adjacent waters.

\section{ACKNOWLEDGEMENT}

This research was based on the data collected during Stock Assessment of Fisheries Resources in Indian Ocean (Fisheries Management Area 573) in 2016 which was supported by Research Institute for Marine Fisheries (RIMF) and funded by government. The authors should thank to researcher group of shrimp in RIMF for their support and in valuable idea for this paper.

\section{REFRENCES}

Bal, D.V., \& K.V. Rao (1984). "Marine fisheries." New Delhi: Tata Mc. Graw-Hill Publishing Company Limited., 5-24 pp.

Effendie, M. I. (2002). Fishery biology (p.136). Yayasan Pustaka Nusatama, Yogyakarta.

Fauzi, M., Prasetyo, A.P., Hargiyatno, I.T., Satria, F., \& Utama, A.A. (2013). The relationship and condition factor of spiny lobster (Panulirus penicillatus) in waters of Gunung Kidul and Pacitan. BAWAL, 5(2),97-102. DOI :http:// dx.doi.org/10.15578/bawal.5.2.2013.97-102

Gayanilo, F.C.Jr., Sparre, P. P., \& Pauly, D. (2005). FAO-ICLARM stock assessment tools II (FiSAT II). Revised version. User's guide. FAO Computerized Information Series (Fisheries). No. 8, Revised version. Rome, FAO. 168 p.

Herdianto, D.A., \& Riswanto (2014). Biology characteristic of endeavour shrimp (Metapenaeus affinis Milne-Edward 1837) in Kubu Raya waters, West Kalimantan. Proceeding of Fisheries National Seminar, 83-89.

King, M. (1995). Fisheries biology: assessment and management (p. 341). Fishing News Books. Oxford, England.

Knaepkens, G., Knapen, D, Bervoets, L., Hanfling, B., Verheyen, E., \& Eens, M. (2002). Genetic diversity and condition factor: a significant 
relationship in Flemish but not in German populations of the the European bullhead (Cottus gobio L.). Heredity, 89, 280-287.

Lestari, P., Tirtadanu., Kembaren, D.D., \& Wedjatmiko (2018). Population parameters of greasyback shrimp (Metapenaeus ensis de Haan) in Bangka Strait, South Sumatera. BAWAL, 10(2), 119-127. DOI: $\quad$ http://dx.doi.org/10.15578/ bawal.10.2.2018.119-127

Martosubroto, P. (1978). Musim pemijahan dan pertumbuhan udang jerbung (Penaeus merguiensis de Man) dan udang dogol (Metapenaeus ensis de Haan) di perairan Tanjung Krawang. Proceeding of Second Seminar of Shrimp Fishery, 7-20.

Naamin, N. (1984). Population dynamic of banana prawn (Penaeus merguiensis de Man) in Arafura waters and its management. Ph.D Disertation at Post Graduate Faculty, IPB Bogor, 381.

Naamin, N., Sumiono, B., llyas, S., Nugroho, D., Iskandar, B.P.S., Barus, H.R., Badrudin, M., Suman, A., \& Amin, E.M. (1992). Technical guides of management and exploitation of Penaeid shrimp resources for fisheries development. Series of Fisheries Research Development No. PHP/KAN/ $P T / 22 / 1992$. Agency for Agricultural Research and Development.

Nikolsky, G. V. (1963). The ecology of fishes (p. 352). Academic Press. New York.

Pauly, D., Ingles, J., \& Neal, R. (1984). Application to shrimp stocks of objective methods for the estimation of growth, mortality and recruitment related parameters from length frequency data (ELEFAN I and II). In: Penaeid shrimp - their biology and management: 220-234. Fishing News Book Limited. Farnham-Surrey-England.

Pauly, D. (1985). Some simple method for the assesment fish stock. FAO Fish. Tech. Paper (234) Rome.

RIMF (2016). Study of fishery biology characteristic, resource habitat and potential yield of fishery resources in Fisheries Management Area (FMA) 573. Final Report. Research Institute for Marine Fisheries-Research and Development Center of Fisheries-Agency for Marine and Fisheries Research and Developpment.
Sivakami, S., Raje, S.G., Khan, M.F., Shobha, J.K., Vivekanandan, E., \& Kumar, U.R. (2001). Fishery and biology of Priacanthus hamrur (Forsskal) along the Indian coast. Indian J. Fish. 48(3), 277-289.

Sparre, P., \& S.C. Venema (1992). Introduction to tropical fish stock assesment. Part I. Manual. FAO Fish. Tech. Pap. No. 306/1.

Sudjastani, T. (1974). Population dynamic of scad in Java sea. Laporan Penelitian Perikanan Laut, (1), 30-64.

Suhendrata, T., \& I.G.S. Merta (1986). Length-weight relationship, maturity stage and fecundity of skipjack, Katsuwonis pelamis (Linnaeus) in Sorong waters. Jurnal Penelitian Perikanan Laut, (34), 1119.

Suman, A., Sumiono, B., \& M. Rijal (1987). Jogol net fishery in Pangandaran, West Java. Jurnal Penelitian Perikanan Laut, (43), 89-98.

Suman, A. (1990). Some biological aspect of endeavour shrimp (Metapenaeus ensis de Haan) in south coast of Java waters. Jurnal Lingkungan dan Pembangunan, 128-134.

Suman, A. (1991). Status of shrimp fishery in Kotabaru waters, South Kalimantan. Proceeding of Meeting Scientific of Artisanal Fishery, p. 22-32.

Suman, A. (1992). Dynamic of endeavour shrimp (Metapenaeus ensis de Haan) in south coast of Java waters. Proceeding Seminar of Marine Ecology, p. 64-71.

Suman, A. (2004). Exploitation pattern of endeavour shrimp resourcesl (Metapenaeus ensis de Haan) in Cilacap and its adjacent waters. Disertation at Post Graduate School, IPB, Bogor.

Suman, A., \& M. Boer (2005). Size at first maturity, spawning season and growth parameter of endeavour shrimp (Metapenaeus ensis de Haan) in Cilacap and adjacent waters. JPPI Edisi Sumber Daya dan Penangkapan Vol. 11 No. 2 : 69-74. DOI: http://dx.doi.org/10.15578/ jppi.11.2.2005.69-74

Suman, A., \& G. Bintoro (2009). Some population parameters of endeavour shrimp (Metapenaeus ensis de Haan) in Balikpapan surrounding waters, East Kalimantan. Ind. Fish. Res. J, 15(1), 75-79. DOI: http://dx.doi.org/10.15578/ifri.15.1.2009.75$\underline{79}$ 
Suman, A., Wudianto., Sumiono, B. , Irianto, H.E., Badrudin., \& Amri, K. (2014). Maximum sustainable yield and exploitation rate of fish resource in Indonesia Fisheries Management Area (p. 199). Ref Grafika Publisher, Jakarta.

Suman, A., B.I. Prisantoso \& D.D. Kembaren (2017). Population parameters of endeavour shrimp (Metapenaeus ensis) and black tiger shrimp (Penaeus monodon) in Arafura sea. BAWAL. 9 (1) April 2017: 57-62. DOI: http://dx.doi.org/10.15578/ bawal.9.1.2017.57-62

Suparjo, M.N. (2005). Potency of endeavour shrimp (Metapenaeus ensis) in Kebumen, Central Java. Study Program of Management of Aquatic Study, Faculty of Marine Science and Fisheries, Diponegoro University: $9 \mathrm{p}$.
Udupa, K.S. (1986). Statistical method of estimating the size at first maturity in fishes. Fishbyte 4 (2): 8 - 10. ICLARM, Metro Manila.

Van Zalinge, N.P. \& N. Naamin (1975). The Cilacap based trawl fishery for shrimp along the south coast of Java. Laporan Penelitian Perikanan Laut No. 2: 1-15.

Walpole, R.V.E. (1993). Introduction to statistics (p. 321). Translation by B. Sumantri (Third edition). Jakarta: PT. Gramedia.

Widodo, J., \& Suadi. (2006). Management of Marine Fisheries Resouces. Universitas Gadjah Mada (ID) Press, Yogyakarta. 